\title{
Analisis Keaktifan Kader Posyandu dalam Pelaksanaan Kegiatan Posyandu
}

Juliana Widyastuti Wahyuningsih
Akademi Kebidanan Budi Mulia Palembang

Informasi Artikel :

Diterima : 15 April 2021

Direvisi : 02 Mei 2021

Disetujui : 25 Mei 2021

Diterbitkan : 15 Juni 2021

*Korespondensi Penulis : yuliana_widyastuti@ymail.com

\section{A B S T R A K}

Posyandu merupakan usaha kesehatan yang dilakukan dari, oleh dan untuk masyarakat, yang dalam pelaksanaanya dilakukan oleh kader yang bersifat dasar. Penelitian ini bertujuan untuk mendapatkan informasi yang mendalam tentang keaktifan kader posyandu di Desa Gedung Agung Kecamatan Merapi Timur Kabupaten Lahat yang berkaitan dengan pengetahuan, sikap kader posyandu, sarana dan prasarana kesehatan yang ada di posyandu serta peran tokoh masyarakat. Metode yang digunakan adalah studi analisis deskriftif dengan menggunakan pendekatan kualitatif. Informasi didapat dengan menggunakan Wawancara Mendalam (WM) dengan informan kunci 4 orang dan Focus Group Discussion (FGD) sebanyak 2 kelompok atau 16 orang. Informasi dianalisa secara manual, keabsahan informasi dilakukan dengan cara Triangulasi sumber dan Triangulasi metode. Dari hasil penelitian terhadap informasi peserta FGD diketahui bahwa pengetahuan mengenai tugas dan peran kader sudah cukup baik, walaupun mereka hanya menjelaskan secara garis besarnya saja, hal inipun sama dengan hasil peserta WM bahwa mereka masih sangat kurang dalam menyampaikan pengetahuan mengenai tugas dan peran kader posyandu. Untuk sikap yang diberikan oleh peserta FGD dan WM sudah cukup baik walaupun masih ada dari peserta FGD yang bersikap kurang perduli dengan tugas dan perannya di posyandu. Sarana dan prasarana kesehatan yang ada sudah dapat digunakan dalam pelaksanaan kegiatan posyandu walaupun masih perlu dilengkapi lagi. Untuk peranan Kepala Desa sebagai tokoh masyarakat cukup mendukung dengan pelaksanaan kegiatan posyandu. Disimpulkan bahwa pengetahuan mengenai tugas dan peran kader di posyandu sangat penting untuk menunjang keaktifan kader posyandu. Adapun saran - saran yang diajukan kiranya dapat bermanfaat dan menunjang semua pihak khususnya kader posyandu desa Gedung Agung Kecamatan Merapi Kabupaten Lahat.

Kata Kunci : Kader Posyandu, Imunisasi

\section{ABSTRACT}

Posyandu is healthy care that hold from, by and for society, that in it's accomplishment done by cadre that has the character of base.

The purpose of this research to get the circumstantial information about the activity cadres posyandu at Gedung Agung village Merapi Timur subdistrict Lahat who related with knowledge attitude cadres posyandu, the health instruments at posyandu and acts the society figure. The method of reseach of FGD competitor information that knowledge of concerning jobs and acts cadres have good enough although they just could explain it's main features only. And they still less in submitting knowledge concerning jobs and acts cadres posyandu. For the attitude that given by FGD and WM competitor have good enough eventhough the attitude some competitor less care they jobs and acts posyandu.the health instruments that they have can use for execution posyandu activity although need to be complete. The 
village leader part as society figure is have good enough support to execution of posyandu activity. The conclude the knowledge that concerning prevention jobs and acts cadres posyandu is very importance to support the activity cadres posyandu. There are suggestion that can be useful and support all direction particularly cadres posyandu Gedung Agung Village Merapi Timur subdictrict Lahat.

Keywords : Posyandu Cadre Immunization

\section{PENDAHULUAN}

Pembangunan kesehatan adalah bagian dari pembangunan nasional yang bertujuan meningkatkan kesadaran, kemauan, dan kemampuan untuk hidup sehat bagi setiap orang agar terwujud derajat kesehatan masyarakat yang setinggi-tingginya. Pembangunan kesehatan tersebut upaya seluruh potensi bangsa Indonesia baik masyarakat, swasta maupun pemerintah. ( Depkes, 2004 )

Pelayanan kesehatan utama (primary healh care) merupakan pendekatan praktis untuk melaksanakan perawatan kesehatan masyarakat ditingkat individu, keluarga, masyarakat atau komunitas dalam bentuk yang dapat diterima sesuai dengan kemampuan yang dimiliki dengan melibatkan partisipasi sepenuhnya dari masyarakat dan operasionalnya di indonesia dalam bentuk pembangunan kesehatan masyarakat desa dengan nyata yang melibatkan partisipasi masyarakat melalui pos pelayanan terpadu ( Posyandu ). ( Effendy, 1998 ).

Pusat Kesehatan Masyarakat ( Puskesmas) adalah satuan organisasi fungsional yang menyelenggarakan upaya kesehatan yang bersifat menyeluruh, terpadu, merata, dapat diterima dan terjangkau oleh masyarakat, dengan peran aktif masyarakat dan menggunakan hasil pengembangan ilmu pengetahuan dan teknologi tepat guna, dengan biaya yang dapat dipikul oleh pemeritah dan masyarakat. Upaya kesehatan tersebut diselenggarakan dengan menitik beratkan kepada pelayanan untuk masyarakat luas guna mencapai derajat kesehatan yang optimal, tanpa mengabaikan mutu pelayanan kepada perorangan.( Dinkes Prov Sumsel 2016 )
Posyandu (Pos Pelayanan Terpadu) merupakan salah satu bentuk Upaya Kesehatan Bersumber daya Masyarakat (UKBM) yang dilaksanakan oleh, dari, dan bersama masyarakat, untuk memberdayakan dan memberikan kemudahan kepada masyarakat guna memperoleh pelayanan kesehatan bagi ibu, bayi, dan anak balita. (Profil Kesehatan Indonesia, 2019)

Pada tahun 2019, terdapat 296.777 Posyandu di seluruh Indonesia. Sebanyak 188.855 atau sekitar $63,6 \%$ posyandu diantaranya merupakan posyandu aktif. Posyandu aktif adalah posyandu yang mampu melaksanakan kegiatan utamanya secara rutin setiap bulan (KIA: ibu hamil, ibu nifas, bayi, balita, KB, imunisasi, gizi, pencegahan, dan penanggulangan diare) dengan cakupan masingmasing minimal 50\% dan melakukan kegiatan tambahan. (Profil Kesehatan Indonesia, 2019).

Proses pelaksanaan kegiatan posyandu memberikan pelayanan dengan menggunakan pelayanan lima meja dimana pelayanan meja I sampai meja IV, dilaksanakan oleh kader yang sudah dilatih yaitu pendaftaran, penimbangan, pencatatan dan penyuluhan, meja $\mathrm{V}$ yaitu pelayanan kesehatan dan $\mathrm{KB}$ dimana dilaksanakan oleh tenaga kesehatan ( Efendy, 1998 ).

Dalam kegiatan posyandu yang dipakai untuk menggambarkan hasil kegiatan adalah pencapaian SKDN, dimana S adalah jumlah seluruh balita diwilayah kerja posyandu, K adalah jumlah balita yang memiliki KMS, D adalah jumlah balita yang ditimbang dan $\mathrm{N}$ adalah jumlah balita yang naik berat badannya dari timbangan bulan sebelumnya ( Dinkes Prop Sumsel, 2014 ).

Akhir-akhir ini kegiatan posyandu secara nasional kurang menggembirakan, pada tahun 2012 jumlah posyandu di 
Indonesia 273.483 buah dengan kader aktif 1.807.208 orang. Sedangkan di Sumatera selatan pada tahun 2013 jumlah posyandu 5902 buah dengan kader aktif 24.017 orang ( $66.34 \%$ ), pada tahun 2014 ada 5950 posyandu terdiri dari posyandu purnama 1.563 buah ( $26.27 \%$ ) dan posyandu mandiri 167 buah ( $2.81 \%$ ) Pada tahun 2015 jumlah posyandu 2621 buah atau $94,34 \%$ dari desa yang ada. Tahun 2016 terdapat 5786 buah posyandu dengan jumlah kader 32.131 orang, kader aktif 21.988 orang $(64,84 \%)$ dan yang tidak aktif 10.143 orang $(31,50 \%)$. (Dinkes Prov Sumsel 2016 )

Di Kabupaten Lahat pada tahun 2014 terdapat 590 posyandu dengan kader aktif 2.249 orang ( $87.7 \%$ ), tahun 2015 ada 592 posyandu dan 3.015 kader aktif ( $73 . \%$ ) sedangkan pada tahun 2016 terdapat 589 posyandu dengan kader aktif 2.615 orang ( $87.43 \%$ ). ( Dinkes Kab Lahat, 2016 )

Untuk binaan Puskesmas Muara Lawai Kecamatan Merapi Timur terdiri dari 6 desa dengan jumlah posyandu 10 buah. Kader yang terdaftar pada tahun 2014 ada 45 orang dengan jumlah kader yang aktif sebanyak 27 orang ( $60 \%$ ), sedangkan pada tahun 2015 terdapat 10 posyandu dengan kader terdaftar 45 orang kader dan yang aktif hanya 29 orang (64\%). Pada tahun 2016 terdapat peningkatan jumlah kader yang terdaftar menjadi 50 orang dan yang aktif 30 orang ( $60 \%$ ). Desa Gedung Agung Kec Merapi Timur terdiri dari 5 dusun dengan 5 posyandu dengan jumlah kader terdaftar 25 orang, pada tahun 2014 kader aktif sebanyak 18 orang ( $72 \%$ ), terjadi penurunan pada tahun 2015 kader aktif 13 orang ( 52\% ) dan pada tahun 2016 dari 25 orang kader yang ada yang aktif hanya 10 orang ( $40 \%$ ) saja.( Puskesmas Muara Lawai, 2016 )

Dari permasalahan diatas menarik minat penulis untuk meneliti tentang kader posyandu, mengingat posyandu merupakan salah satu tolak ukur keberhasilan program puskesmas. Berdasarkan uraian tersebut maka peneliti berkeinginan untuk mengetahui secara lebih mendalam mengenai keaktifan kader dalam pelaksanaan posyandu didesa tersebut.

\section{METODE PENELITIAN}

Penelitian ini merupakan studi Analisa Deskriftif dengan menggunakan pendekatan kualitatif untuk mendapatkan informasi mendalam tentang masalah dan perilaku kader khususnya keaktifan kader posyandu dalam pelaksanaan kegiatan posyandu. Penelitian ini dilakukan terhadap kader posyandu untuk mendapatkan informasi mengenai pengetahuan dan sikap kader akan tugas dan perannya di posyandu.

Penelitian dilaksanakan di Desa Gedung Agung Kecamatan Merapi Timur Kabupaten Lahat dengan pertimbangan masih kurangnya keaktifan kader posyandu di desa tersebut. Penelitian ini dilakukan pada tanggal 18 Maret 2021 sampai 17 April 2021. Informasi yang didapatkan adalah informasi primer, karena peneliti langsung memperoleh dari sumber informasi yaitu : Pimpinan puskesmas, juru imunisasi, Bidan desa, Tokoh masyarakat dan kelompok kader. Untuk menjamin keabsahan informasi dalam penelitian ini, dilakukan triangulasi sumber dengan pengecekan ulang antara informan yang satu dengan yang lainnya. Selain itu dilakukan triangulasi metode yaitu dengan membandingkan informasi yang diperoleh dari hasil wawancara mendalam dan Focus Group Discussion. Hasil wawancara mendalam dan diskusi kelompok terarah (FGD), baik dalam bentuk rekaman maupun catatan yang dikumpulkan, kemudian diolah menjadi traskip dan matrik dan selanjutnya dilakukan analisis secara manual terhadap isi penelitian ( Content Analysis ).

\section{HASIL PENELITIAN}

\section{Gambaran Umum Desa Gedung Agung}

Dengan luas wilayah $296 \mathrm{Ha}$ desa Gedung Agung terdiri atas lima dusun yaitu dusun I sampai dengan dusun V. Jarak dari desa ke ibu kota kecamatan $3 \mathrm{~km}$ dan jarak ke ibu kota kabupaten $37 \mathrm{~km}$. Adapun batas - 
batas wilayah desa Gedung Agung sebagai berikut :

a. Sebelah utara berbatasan dengan sungai Lematang

b. Sebelah selatan berbatasan dengan Perkebunan rakyat

c. Sebelah timur berbatasan dengan desa Tanjung Jambu

d. Sebelah barat berbatasan dengan desa Arahan

Jumlah penduduk desa Gedung Agung sampai dengan bulan Desember 2020 adalah 2199 jiwa, dengan jumlah penduduk laki laki 1032 jiwa dan perempuan 1167 jiwa, jumlah kepala keluarga 523 kk.

\section{Karakteristik Informan}

Key Informan pada wawancara mendalam (WM) berjumlah 4 orang, dimana peserta WM adalah orang-orang yang jabatan atau kedudukan dan sangat berhubungan dengan penelitian ini seperti pimpinan puskesmas, juru imunisasi, bidan desa, dan tokoh masyarakat. Untuk lebih terperinci mengenai karakteristik peserta WM dapat dilihat pada tabel berikut :

Tabel 1 Karakteristik Informan Kunci Menurut Umur, Pendidikan dan Jabatan

\begin{tabular}{cccll}
\hline No & Inisial & Umur & Pendidikan & \multicolumn{1}{c}{ Pekerjaan } \\
\hline 1. & LT & 27 & S I & Pimpinan \\
2. & MY & 35 & Kedokteran & Puskesmas \\
3. & SL & 32 & D I Kebidanan & Bidan Desa \\
4. & RD & 55 & $\begin{array}{l}\text { D I Kebidanan } \\
\text { SLTA }\end{array}$ & $\begin{array}{l}\text { Juru Imunisasi } \\
\text { Kepala Desa }\end{array}$ \\
\hline
\end{tabular}

Sementara informan yang hadir dalam Focus Group discussion (FGD) adalah kader posyandu Desa Gedung Agung Kec. Merapi Timur yang berjumlah 16 orang yang terdiri dari 2 kelompok, tiap kelompok berjumlah 8 orang, dimana pembagian kelompok berdasarkan keaktifan mereka di Posyandu. Kelompok pertama adalah kelompok yang aktif di posyandu sedangkan kedua adalah kelompok kader yang kurang aktif di posyandu. Untuk lebih terperinci mengenai karakteristik peserta FGD dapat dilihat pada tabel berikut :

Tabel 2 Karakteristik Informan Peserta FGD Menurut Umur, Pendidikan dan Pekerjaan Kelompok Kader Aktif

\begin{tabular}{ccccc}
\hline No & Inisial & Umur & Pendidikan & Pekerjaan \\
\hline 1. & NR & 24 & SLTP & Ibu RT \\
2. & MF & 29 & SLTA & Guru SD \\
3. & KR & 27 & SD & Ibu RT \\
4. & TR & 27 & SLTP & Ibu RT \\
5. & HR & 19 & SLTP & Ibu RT \\
6. & ST & 18 & SLTP & TOT \\
7. & SY & 32 & SD & Ibu RT \\
8. & MK & 34 & SD & Ibu RT \\
\hline
\end{tabular}

Tabel 3 Karakteristik Informan Peserta FGD Menurut Umur, Pendidikan dan Pekerjaan Kelompok Kader Kurang Aktif

\begin{tabular}{ccccc}
\hline No & Inisial & Umur & Pendidikan & Pekerjaan \\
\hline 1. & RD & 27 & SD & Ibu RT \\
2. & Mt & 25 & SLTP & Ibu RT \\
3. & NS & 29 & SD & Ibu RT \\
4. & MI & 17 & SLTP & TOT \\
5. & PA & 18 & SLTP & TOT \\
6. & HA & 39 & SLTA & Ibu RT \\
7. & JU & 37 & SD & Ibu RT \\
8. & SR & 23 & SD & Ibu RT \\
\hline
\end{tabular}

\section{Faktor Predisposisi}

a. Pengetahuan Tentang Posyandu

1) Pengertian Posyandu

Informasi yang diperoleh dari peserta FGD dari 16 peserta yang memberikan jawaban sebanyak 10 orang yaitu 6 orang dari kelompok kader aktif dan 4 orang dari kelompok kader kurang aktif. Sedangkan 6 peserta yang lainnya hanya menggelengkan kepala dan tidak memberikan jawaban. Informasi mengenai pengertian Posyanduantara lain sebagai berikut :

Kelompok kader aktif :

“... Posyandu tu pelayanan kesehatan dari masyarakat umtuk masyarakat, digawika le masyarakat tula " (MF)

(Posyandu itu pelayanan kesehatan dari masyarakat untuk masyarakat, yang dikerjakan oleh masyarakat itu sendiri)

Kelompok kader kurang aktif : 
"Oh... posyandu tu bada nibang, imunisasi bayi digaweka oleh kader nga bidan." ( RD )

2) Kegiatan Posyandu

Dari peserta FGD hanya 9 orang peserta yang memberikan jawaban yaitu 5 orang dari kelompok kader aktif dan 4 orang dari kelompok kader kurang aktif. Sementara 7 orang lainnya hanya menggelengkan kepala dan diam. Untuk kegiatan posyandu menurut peserta FGD antara lain sebagai berikut :

Kelompok kader aktif :

"Kegiatan-kegiatan ye ade di posyandu penimbangan, imunisasi, periksa ibu hamil, makanan tambahan." (MF)

( Kegiatan-kegiatan yang ada di posyandu penimbangan, imunisasi, periksa ibu hamil, makanan tambahan)

Kelompok kader kurang aktif :

"Nimbang nga imunisasi." (MT)

( Menimbang dan imunisasi )

"Ade makanan tambahan nek balita pule." (MI)

( Ada makanan tambahan untuk balita juga )

\section{3) Sasaran Posyandu}

Dari peserta FGD hanya 10 orang peserta yang memberikan jawaban, dari kelompok kader aktif 5 orang dan 5 orang dari kelompok kader kurang aktif. Dan 6 orang lainnya hanya menggelengkan kepala dan diam. Untuk kegiatan posyandu menurut peserta FGD antara lain sebagai berikut :

Kelompok kader aktif :

" Bayi, ibu hamil, pasangan usia subur, balita kurang gizi " (NR)

"Bayi ye nek imunisasi, ibu hamil ye nek perikse." (MK)

( Bayi yang mau imunisasi, ibu hamil yang mau periksa)

Kelompok kader kurang aktif :

" Bayi, ibu hamil, balita, betine ye nak KB." (MT)

( Bayi, ibu hamil, balita, wanita yang mau $\mathrm{KB})$

4) Tugas dan Peran Kader

Hasil wawancara mendalam secara umum Key Informan memberikan informasi mengenai tugas dan peran kader yang berdasarkan mereka ketahui sebagai berikut :

" Menurut saya tugas dan peran kader adalah menyiapkan alat-alat yang diperlukan untuk posyandu, melaksanakan tugas-tugas di lima meja, mendorong masyarakat untuk aktif di posyandu terutama yang ada anak bayi dan balita." (LT)

Untuk tugas dan peran kader dari 16 peserta yang memberikan jawaban sebanyak 9 peserta yaitu 5 orang dari kelompok kader aktif dan 4 orang kelompok kader kurang aktif. Sedangkan 7 orang peserta yang lain tidak memberikan jawaban hanya menggelengkan kepala. Informasi tersebut adalah :

Kelompok kader aktif :

" Mbantu petugas kesehatan melayani masyarakat di posyandu misalnye nimbang, ngisi KMS...selain itu mantaui ibu-ibu ye hamil nga ade bayi kalu ka posyandu." (MF)

( membantu petugas kesehatan melayani masyarakat di posyandu misanya menimbang, mengisi KMS... selain itu memanggil ibu-ibu yang hamil dan ada bayi kalau mau posyandu )

Kelompok kader kurang aktif :

"Nolongi bidan nimbang, nyatat biasenye." (MT) (Menolong bidan menimbang, biasanya mencatat)

5) Kegiatan ditiap Meja Posyandu

Dari hasil FGD 7 peserta yang memberikan informasi mengenai kegiatan apa saja yang ada di tiap meja posyandu yaitu 4 orang dari kelompok kader aktif dan 3 orang dari kelompok kader kurang aktif. Sedangkan 9 peserta FGD yang lain menggelengkan kepala dan diam yaitu antara lain:

Kelompok kader aktif :

“ ....Meja I pendaftaran, meja II penimbangan, meja III pengisian KMS, meja IV imunisasi dan meja V penyuluhan. " (MF) Kelompok kader kurang aktif :

"Meja di posyandu tu ade meja bada ndaftar, bada nimbang, bada ngisi KMS bayi nga meja imunisasi. “(MI) 
( Meja di posyandu itu ada meja tempat mendaftar, tempat menimbang, tempat mengisi KMS bayi dan meja imunisasi )

\section{6) Cara Pendaftaran}

Untuk kegiatan pendaftaran dari 16 peserta yang memberikan jawaban sebanyak 8 peserta yaitu 5 orang dari kelompok kader aktif dan 3 orang dari kelompok kader kurang aktif. Sedangkan 8 orang peserta yang lain tidak memberikan jawaban hanya diam. Informasi tersebut antara lain :

Kelompok kader aktif :

"Langsung daftar saje kele ade kader ye nyatatnye"(NR)

( Langsung mendaftar saja nanti ada kader yang mencatatnya)

Kelompok kader kurang aktif :

" Tanyeka nga jemenye, udemtu langsung catat saje name siape ye nak imunisasi, kami kan ade bukunye..... " (PA)

( Tanyakan dengan orangnya, setelah itu langsung catat saja nama siapa yang hendak imunisasi, kami ada bukunya )

\section{7) Penimbangan}

Dari hasil FGD 7 peserta yaitu 4 orang dari kelompok kader aktif dan 3 orang dari kelompok kader kurang aktif memberikan informasi mengenai kegiatan penimbangan. Sedangkan 9 peserta FGD yang lain menggelengkan kepala yaitu :

Kelompok kader aktif :

" Kalu nak nimbang ?... bayi dimasukkan ke dalam dacin mangke ditimbang berape timbangannye. " (KR)

( kalau mau menimbang bayi dimasukkan ke dalam dacin lalu ditimbang berapa timbangannya )

Kelompok kader kurang aktif :

"Amu nak nimbang carenya masuka bayi tu ke dalam dacin udemtu make ditimbang mangke kina'i behape timbangannye. " (PA)

( Kalau mau nimbang caranya masukkan bayi itu ke dalam dacin kemudian ditimbang lantas dilihat berapa beratnya )

\section{8) Pengisian KMS}

Untuk kegiatan pengisian KMS dari 16 peserta yang memberikan jawaban sebanyak 8 peserta yaitu 4 orang dari kelompok kader aktif dan 4 orang dari kelompok kader kurang aktif. Sedangkan 8 orang peserta yang lain tidak memberikan jawaban hanya diam. Informasi tersebut antara lain :

Kelompok kader aktif :

"Ngisi KMS itu hasil timbangan berat badan bayi tadi dibuat di grafik ye ade didalam KMS sesuai nga umur budak tu. " ( MF )

( Mengisi KMS itu hasil menimbang berat badan bayi tadi dibuat di grafik yang ada di dalam KMS sesuai dengan umur anak itu.)

Kelompok kader kurang aktif :

" Berape hasil timbangan bayi dibuat titik di kotak - kotak dalam KMS sesuai dengan umurnye. " (HA)

( Berapa hasil timbangan bayi dibuat titik di kotak-kotak dalam KMS sesuai dengan umurnya)

9) Pengaturan Pelaksanaan Posyandu

Hasil wawancara mendalam dengan

Key Informan mengenai pengaturan pelaksanaan posyandu yaitu antara lain :

" Jadwal posyandu sudah disetujui oleh masyarakat tapi kalau ada musibah atau hajatan warga, posyandu bisa diundur jadwalnyo atau ketepatan hari libur sama jugo macam itulah." (MY)

"Sebisa mungkin jadwal tetap kecuali ada halangan yang berarti bisa ditunda dulu." (RD)

\section{0) Petugas Pelaksana di Posyandu}

Untuk petugas pelaksana di posyandu dari 16 peserta yang memberikan jawaban sebanyak 10 peserta yaitu 5 orang dari kelompok kader aktif dan 5 orang dari kelompok kader kurang aktif. Sementara 6 orang peserta lainnya tidak memberikan jawaban hanya menganggukkan kepala. Informasi tersebut antara lain :

Kelompok kader aktif :

" selain Bidan ade perawat ye galak datang imunisasi, kadant-kadang dokter ade anye dek tentu kapan die datang." (MF) 
( Selain Bidan ada perawat yang datang imunisasi, kadang-kadang dokter ada tapi tidak tentu kapan dia datang )

Kelompok kader kurang aktif :

"Asenye bidan tula, kadang ade kancenye sandi Puskes." (RD)

( Rasanya bidan saja, kadang ada temannya dari Puskes)

Hasil wawancara mendalam dengan Key Informan mengenai Petugas Pelaksana di Posyandu

"Kalau desa yang ada petugasnya mereka yang bertanggung jawab langsung tapi kalau desa yang tidak ada petugasnya di bagi petugas yang ada dipuskesmas sebagai penjawil atau penanggung jawab wilayah." (LT)

" Aku Cuma melaksanake Posyandu di desa aku dewek, inipun sudah banyak karena ada lima dusun tapi ado kawan dari puskes yang bantu." (MY)

\section{1) Pelatihan Bagi Kader}

Untuk Pelatihan bagi kader dari 16 peserta yang memberikan jawaban sebanyak 10 orang peserta yaitu 6 orang dari kelompok kader aktif dan 4 orang dari kelompok kader kurang aktif. Sedangkan 6 peserta yang lain memberikan jawaban dengan menganggukkan kepala dan menjawab ya.

Kelompok kader aktif :

" Dek keruan ige, anye asenye aku dek kela diajak penataran." (KR)

( Tidak tahu betul, tapi rasanya saya tidak pernah diajak penataran)

" kebile pule ade penataran ? galak ige aku amu diajak." (SY)

( kapan pula ada penataran ? saya senang betul kalu diajak)

Kelompok kader kurang aktif :

" la lame juge dide tedengar ade penataran, entah ye baru-baru ni...." (RD)

( sudah lama juga tidak terdengar ada penataran, entah yang baru-baru ini..)

" dide bedie penataran nek kami." (PA)

( tidak ada penataran untuk kami)

Hasil wawancara mendalam dengan

Key Informan mengenai bimbingan dan pelatihan bagi kader yaitu
" Rasanya sudah lama ada pelatihan untuk kader, tapi saya lupa kapan. Kalau untuk bimbingan tentang tugas kader bisa diberikan kapan saja." (SL)

" Belum ada lagi informasi pelatihan untuk kader, kalau bimbingan yang saya berikan paling-paling agar mereka lebih rajin keposyandu." (RD)

\section{2) Penghargaan Bagi Kader}

Hasil wawancara mendalam dengan

Key Informan mengenai penghargaan bagi kader yaitu :

" Kalu dari puskesmas belum ada, paling kalau ada pertemuan mereka diajak. Selam ini yang bisa kita berikan pada mereka ada uang tranport Rp. 5.000,- perbulan untuk tiap kader yang datang, selain itu seragam untuk lima orang kader ditiap desa." (LT)

"Belum ada, kalau menurut kami memang seharusnya ada supaya para kader lebih rajin dan giat lagi keposyandu. Bentuknya tergantung pihak yang akan memberikan." (RD)

Untuk penghargaan bagi kader dari 16 peserta FGD sebagian peserta atau 8 orang memberikan jawaban yaitu 5 orang dari kelompok kader aktif dan 3 orang dari kelompok kader kurang aktif. Sedangkan 8 peserta lainnya mengangguk dan tidak menjawab. Dan informasi tersebut antara lain sebagai berikut :

Kelompok kader aktif :

" Dek bedie penghargaan nek kami paling ade baju seragam, duet transport Rp5.000,00 sebenarnye kecik ige anye." (MF)

( Tidak ada penghargaan bagi kami paling ada baju seragam, uang transport $\mathrm{Rp}$ 5.000,00 sebenarnya terlalu kecil )

Kelompok kader kurang aktif :

"Dek bedie anye dide pule ngarap ige" (DU)

( Tidak ada cuma tidak terlalu berharap )

b. Sikap Terhadap Pelaksanaan Posyandu

1) Sikap Terhadap Petugas Kesehatan yang Kurang Aktif

Hasil wawancara mendalam dengan Key Informan memberikan pendapat mereka 
mengenai petugas kesehatan yang kurang aktif antara lain sebagai berikut :

"Itulah, masyarakat kita ini kan suka meniru nah, jeleknya kalau yang niru itu tidak baik seperti ibu katakan tadi petugas yang kurang aktif aku khawatir ini akan berpengaruh pada kader meniru jadi malas juga." (RD)

Untuk sikap petugas kesehatan yang kurang aktif dari 16 peserta yang memberikan jawaban 8 peserta yaitu 4 orang dari kelompok kader aktif dan 4 orang dari kelompok kader kurang aktif. Sedangkan 8 peserta lainnya hanya diam. Dan informasi tersebut antara lain sebagai berikut :

Kelompok kader aktif:

"Amu petugas malas, kader mikut malas pule." (KR)

( Kalau petugas malas, kader ikutan malas pula)

Kelompok kader kurang aktif :

"Laporka Nga pak Kades atau dokter." (HA)

(Laporkan dengan Pak Kades atau Dokter)

\section{2) Sikap Terhadap Kader yang Kurang Aktif}

Hasil wawancara dengan Key Informan memberikan pendapat mereka mengenai sikap terhadap kader yang kurang aktif antara lain sebagai berikut :

"Ya... ini salah satu yang kita hadapi sekarang ini, sudah diberi pengertian ke kadernya kenapa jadi males ke posyandu? Kalau memang sudah tidak mau lagi mungkin kita cari yang lain yang mau saja." (LT)

Untuk sikap Kader yang kurang aktif dari 16 peserta yang memberikan jawaban 9 peserta yaitu 5 orang dari kelompok kader aktif dan 4 orang dari kelompok kader kurang aktif. Sedangkan 7 peserta lainnya hanya diam. Dan informasi tersebut antara lain sebagai berikut :

Kelompok kader aktif:

" Dek setuju nian aku, kalu dindak agi jadi kader behenti saje." (NR)

(tidak setuju sekali saya, kalau tidak mau lagi jadi kader berhenti saja)

Kelompok kader kurang aktif :
" Mungkin Banyak gawi, tape kami ni bekebun amu dek digawika luk mane nak makan." (RD)

(Mungkin banyak kerjaan, Kami ini berkebun kalau tidak dikerjakan bagaimana mau makan)

3) Sikap Terhadap Sasaran yang Kurang Aktif

Hasil wawancara mendalam dengan Key Informan mengenai sikap sasaran yanag kurang aktif antara lain sebagai berikut :

"Sayang sekali kalau mereka sampai tidak datang, rugi sekali karena tidak bisa mendapatkan apa yang dilayani di posyandu seperti imunisasi dan lain lain ." (RD)

Untuk sikap sasaran yang kurang aktif dari 16 peserta yang memberikan jawaban 7 peserta yaitu 4 orang dari kelompok kader aktif dan 3 orang dari kelompok kader kurang aktif. Sedangkan 9 peserta lainnya hanya diam. Dan informasi tersebut antara lain sebagai berikut :

Kelompok kader aktif :

"Terserah yang penting la diomongka kalu nak posyandu." (TR)

(Terserah yang penting sudah dikatakan kalau mau posyandu)

Kelompok kader kurang aktif :

" Ye penting la diomongka amu ka posyandu." (PA)

(Yang penting sudah diomongkan kalau mau posyandu)

\section{Faktor Pemungkin}

a. Sarana dan Prasarana Kesehatan

Hasil wawancara mendalam dengan

Key Informan mengenai sarana dan prasarana kesehatan antara lain sebagai berikut :

" Menurut saya cukup lengkap seperti dacin, timbangan, meja, kursi, alat tulis, alat masak untuk makanan tambahan." (LT)

Untuk sarana dan prasarana dari 16 peserta yang memberikan jawaban 7 peserta yaitu 4 orang dari kelompok kader aktif dan 3 orang dari kelompok kader kurang aktif. Sedangkan 9 peserta lainnya hanya diam. Dan informasi tersebut sebagai berikut : 
Kelompok kader aktif :

"Jadilah, alat-alat nek nimbang ade." (NR)

(Cukuplah, alat-alat untuk nimbang ada)

"Meja masih kurang amu pacak ditambahi." (TR)

(Meja masih kurang kalau bisa ditambahi)

Kelompok kader kurang aktif :

"Amu nak imunisasi pacaklah." (MI)

(Kalau untuk imunisasi bisalah)

"Tambah lagi mejanye mangke lemak." (HA)

(Tambah lagi mejanya supaya enak )

b. Pelaksanaan Posyandu Bila Sarana Tidak Memadai

Hasil wawancara mendalam dengan

Key Informan mengenai sarana dan prasarana kesehatan yang tidak memadai antara lain sebagai berikut :

"Kalau sarana yang tidak lengkap lebih baik mengajukan permintaan ke puskesmas supaya diteruskan ke dinas." (SL)

Untuk sarana dan prasarana yang kurang memadai dari 16 peserta yang memberikan jawaban 7 peserta yaitu 4 orang dari kelompok kader aktif dan 3 orang dari kelompok kader kurang aktif. Sedangkan 9 peserta lainnya hanya diam. Dan informasi tersebut antara lainsebagai berikut :

Kelompok kader aktif :

"Kurang lancar." (MF)

"Buat permintaan kebidan." (TR)

Kelompok kader kurang aktif :

"Buat laporan kebidan nga kades." (HA)

(Buat laporan kebidan dan kades)

"Selame ini masih pacak posyandu jadilah." (SR)

(Selama ini masih bisa posyandu, cukuplah)

\section{Faktor Penguat}

1. Tokoh Masyarakat Dan Perannya

Hasil wawancara mendalam dengan

Key Informan mengenai tokoh panutan dan peranannya di posyandu antara lain sebagai berikut :

"Yang dituakan di desa tersebut seperti pak kades. Perannya cukup baik dengan menyediakan tempat untuk posyandu dan mengajak masyarakat desanya untuk datang ke posyandu." (LT)

"Yang dituakan di desa ini seperti Kiayi, perannya baik karena beliau sangat menganjurkan masyarakat untuk rajin ke posyandu. Kalau saya sebagai pemerintahan disini hanya melakukan apa yang saya bisa bantu selain itu memeng kewajiban saya." (RD)

Untuk tokoh masyarakat dan peranannya dari 16 peserta yang memberikan jawaban 7 peserta yaitu 4 orang dari kelompok kader aktif dan 3 orang dari kelompok kader kurang aktif . Sedangkan 9 peserta lainnya hanya diam. Dan informasi tersebut antara lain sebagai berikut :

Kelompok kader aktif :

" Dukung gale dengan kesehatan posyandu misalnye kadang-kadang keposyandu." (MF)

(Mendukung semua dengan kesehatan posyandu misalnya kadang-kadang pergi ke posyandu)

Kelompok kader kurang aktif :

" Jadilah kalu nak posyandu diumumka tula oleh kades." (RD)

(Jadilah kalau akan posyandu selalu diumumkan oleh kades)

"Kadang pak kades datang kalu posyandu." (MT)

(Kadang Pak Kades datang kalau posyandu)

\section{PEMBAHASAN}

1. Faktor Predisposisi

a. Pengetahuan

Informasi yang didapat dari peserta FGD yaitu kelompok kader aktif dari 6 orang yang menjawab 4 orang sudah benar dalam menyebutkan pengertian posyandu dan 2 orang lagi masih memberikan jawaban yang kurang tepat, sementara pada kelompok kader kurang aktif dari 4 orang yang menjawab 3 orang menjawab dengan benar dan hanya 1 orang yang menjawab kurang tepat. Mereka mengatakan oleh masyarakat bahwa posyandu merupakan pelayanan kesehatan yang dilaksanakan oleh masyarakat, untuk kepentingan masyarkat yang berguna untuk pelayanan pada Bayi, Balita dan Ibu hamil. Ini sejalan dengan 
pengertian posyandu adalah pusat kegiatan masyarakat dalam upaya pelayanan Kesehatan dan keluarga Berencana. Effendy (1998).

Informasi yang didapat dari peserta FGD mereka mengetahui kegiatan dan sasaran posyandu walaupun belum secara tepat. Pada kelompok kader aktif 5 orang yang menjawab semuanya memberikan informasi yang benar, demikian pula pada kelompok kader kurang aktif dari 4 orang yang menjawab semuanya memberikan jawaban dengan benar. Mereka mengatakan bahwa kegiatan posyandu adalah penimbangan, pemeriksaan kehamilan, imunisasi dan makanan tambahan bagi balita, dan sasaran posyandu adalah bayi, balita ibu hamil dan pasangan usia subur (PUS). Sedangkan kegiatan posyandu menurut Effendy (1998) adalah Kesehatan Ibu dan Anak (KIA), KB, Imunisasi, Peningkatan dan Perbaikan Gizi Keluarga serta Penanggulangan Diare. Dan sasaran posyandu menurut Effendy (1998) adalah Bayi beruusia kurang dari 1 tahun, balita usia 1 sampai 5 tahun, ibu hamil, ibu menyusui, ibu nifas dan pasangan usia subur.

Informasi yang di dapat dari Key Informan mengenai tugas dan peran kader dimana 4 orang key informan tersebut telah dapat menyebutkan tugas dan peran kader, mereka mengatakan bahwa tugas dan peran kader adalah menyiapkan alat-alat yang diperlukan untuk posyandu, melaksanakan tugas di lima meja posyandu dan mendorong masyarkat untuk datang ke posyandu. Sementara hal ini serupa dengan informasi yang diperoleh dari peserta FGD. Sebagian besar atau 9 orang dari 16 peserta FGD yaitu dari 5 orang yang menjawab dari kelompok kader aktif 4 orang menjawab dengan benar dan dari 4 orang kelompok kader kurang aktif 2 orang yang menjawab dengan benar. Secara keseluruhan dapat dinilai bahwa peserta FGD telah dapat menyebutkan tugas dan peran kader walaupun belum secara tepat, mereka mengatakan tugas kader adalah membantu petugas kesehatan, mengerjakan yang ada di tiap meja posyandu dan mengingatkan masyarakat bila akan posyandu. Informasi yang disampaikan oleh peserta FGD dan WM mengenai tugas dan peran kader hampir sama dengan yang dikemukakan oleh Effendy (1998) bahwa Tugas kader posyandu adalah mempersiapkan alat yang diperlukan, melakukan kegiatan posyandu seperti pendaftaran balita dan ibu hamil, menimbang dan mencatat hasil timbangan, memberikan penyuluhan dan mempersiapkan pelayanan kesehatan oleh petugas. Sementara peran kader adalah menyusun catatan kegiatan dan pelaporan kegiatan, mengusahakan dukungan masyarakat, mengadakan kunjungan rumah bagi sasaran yang tidak hadir dan melaporkan kelengkapan alat-alat serta masalah-masalah yang timbul ke Kepala desa.

Dari informasi yang didapatkan dari peserta FGD mengenai Kegiatan yang ada di lima meja posyandu serta cara melakukan kegiatan tersebut bahwa mereka telah dapat menyebutkan kegiatan dan cara melaksanakan kegiatan di lima meja posyandu. Ini terlihat dari 5 orang kelompok kader aktif semuanya menyebutkan dengan benar, dan dari kelompok kader kurang aktif walaupun yang menjawab hanya 4 orang tetapi semuanya memberikan informasi dengan benar. Mereka mengatakan bahwa kegiatan di lima meja posyandu adalah mulai dari meja I yaitu pendaftaran, meja II tempat penimbangan, meja III pengisian KMS, meja IV adalah kegiatan imunisasi dan meja V adalah kegiatan penyuluhan. Menurut Effendy (1998) sistem lima meja pelayanan posyandu adalah : Meja I untuk pendaftaran, pencatatan bayi, balita, ibu hamil, ibu menyusui dan pasangan usia subur. Meja II adalah penimbangan balita dan ibu hamil, meja III pengisian KMS, meja IV untuk diketahuinya berat badan naik atau tidak naik, ibu hamil dengan resiko tinggi, PUS yang ingin mengikuti $\mathrm{KB}$, penyuluhan kesehatan, pelayanan PMT, oralit, vitamin A, tablet FE, kontrasepsi pil ulangan dan kondom dan terakhir meja $\mathrm{V}$ adalah pemberian imunisasi, pemeriksaan kehamilan, pemeriksaan kesehatan dan 
pengobatan, pelayanan kontasepsi IUD dan suntikan.

Dari informasi yang didapatkan dari key informan mengenai pengaturan pelaksanaan dan petugas pelaksana di posyandu mereka mengatakan bahwa posyandu dilaksanakan setiap bulan dengan jadwal dari kesepakatan penduduk dan petugas kesehatan, kecuali ada halangan yang berarti posyandu bisa ditunda. Petugas pelaksana di posyandu adalah bidan desa dan juru imunisasi. Hal ini serupa dengan informasi yang diperoleh dari peserta FGD. Sebagian besar atau 10 orang orang dari 16 peserta FGD yaitu 5 orang dari kelompok kader aktif dan 5 orang dari kelompok kader kurang aktif menyebutkan tugas pelaksana di posyandu adalah bidan dan perawat kadang kadang dokter puskesmas juga ada. Informasi yang disampaikan oleh peserta FGD dan WM mengenai jadwal pelaksanaan posyandu dan petugas pelaksana hampir sama dengan yang dikemukakan Effendy (1998) bahwa jadwal pelaksanaan posyandu setiap bulan disesuaikan dengan situasi dan kondisi desa tersebut dan petugas pelaksana di posyandu adalah juru imunisasi, perawat atau bidan dan ahli gizi.

Informasi yang diperoleh dari key informan mengenai bimbingan dan pelatihan bagi kader bahwa selama ini memang sudah ada pelatihan untuk kader kira-kira 2 tahun yang lalu, dan belum ada lagi sampai sekarang. Bimbingan diberikan sambil pelaksanaan posyandu. Senada dengan informasi yang diperoleh dari peserta FGD sebagian besar atau 10 orang peserta dari 16 peserta FGD yaitu 6 orang dari kelompok kader aktif dan 3 orang dari kelompok kader kurang aktif menyatakan bahwa mereka tidak pernah diberikan pelatihan. Hal ini tidak sejalan dengan yang dikemukakan oleh Notoadmodjo (2003) bahwa pengetahuan merupakan domain yang sangat penting untuk terbentuknya tindakan seseorang karena dari pengalaman dan penelitian ternyata perilaku didasari oleh pengetahuan.

Informasi yang didapat dari key informan penghargaan bagi kader adalah belum ada penghargaan baik dari puskesmas maupun dari masyarakat sendiri selama ini yamg diberikan kepada kader adalah uang transport Rp 5.000,00 perbulan untuk tiap kader yang datang, selain itu seragam untuk lima orang kader ditiap desa, memang seharusnya ada supaya para kader lebih rajin dan giat lagi keposyandu. Bentuk tergantung pihak yang akan memberikan. Hali ini serupa dengan informasi yang diperoleh dari 8 orang peserta FGD yang menjawab yaitu 5 orang dari kelompok kader aktif dan 3 orang kader kurang aktif yang menyatakan bahwa tidak ada penghargaan yang diberikan kepada mereka, dan mereka menyambut baik bila ada penghargaan atas pekerjaan mereka di posyandu. Selama ini yang mereka dapatkan baju seragam dan uang transport Rp5.000,00 yang dirasakan jumlahnya masih sangat kurang. Seperti yang dikatakan Notoadmodjo (2003) bahwa perilaku seseorang dipengaruhi oleh berbagai faktor. Seseorang akan berperilaku positif bila ia merasakan mendapatkan respon yang positif dari lingkungannya.

Dari semua pernyataan pengetahuan yang telah disampaikan oleh informan baik dari peserta WM maupun peserta FGD baik itu dari kelompok kader aktif maupun kelompok kader kurang aktif dapat disimpulkan bahwa pengetahuan kader posyandu desa Gedung Agung Kecamatan Merapi Timur sudah cukup baik mengenai tugas dan peran kader dalam pelaksanaan posyandu dimana mereka sudah dapat menyebutkan dengan benar mengenai hal tersebut. Menurut Notoadmodjo (2003) bahwa tingkatan pengetahuan diukur dengan mendefinisikan sesuatu secara lebih spesifik yang disebut dengan tahu, kemudian mampu menjelaskan dengan benar serta dapat menyebutkan contoh yang disebut dengan paham, dimana pada akhirnya orang tersebut mempunyai kemampuan untuk materi yang telah dipelajari pada kondisi yang sebenarnya. 
b. Sikap Terhadap Pelaksana Posyandu

Informasi yang diperoleh dari key informan mengenai sikap mereka terhadap petugas kesehatan, kader posyandu dan sasaran posyandu yang kurang aktif bahwa mereka menyayangkan jika petugas kesehatan, kader posyandu dan sasaran posyandu tidak aktif karena petugas dan kader posyandu merupakan tenaga pelaksana posyandu dan kurang aktifnya mereka akan menyebabkan kurang maksimalnya pelayanan yang diberikan. Untuk sasaran posyandu yang kurang aktif key informan berpendapat bahwa masyarakat akan rugi karena tidak bisa mendapatkan apa yang dilayani di posyandu seperti imunisasi, tetapi mereka sudah berupaya agar semua sasaran bisa terlayani dengan baik dengan cara memberikan informasi yang lebih sering bila akan posyandu. Sedangkan informasi yang diperoleh dari peserta FGD dari 8 orang yang menjawab dimana 4 orang dari kelompok kader aktif dan 4 orang dari kelompok kader kurang aktif bahwa mereka berpendapat negatif terhadap petugas dan kader yang kurang aktif karena petugas yang kurang aktif berarti memberikan contoh yang tidak baik bagi para kader dan kader yang kurang aktif akan menghambat jalannya pelaksanaan posyandu karena mengabaikan tugasnya di posyandu. Para peserta FGD mengatakan lebih baik mengambil tindakan dengan melaporkan ke pihak puskesmas dan kepala desa serta mengganti kader yang kurang aktif dengan masyarakat yang lain. Sedangkan untuk sasaran yang kurang aktif para peserta FGD yaitu 4 orang dari kelompok kader aktif mereka berpendapat bahwa sasaran akan rugi padahal posyandu bertujuan untuk menjaga kesehatan anak mereka. Padahal para kader sudah sering memberikan informasi kepada masyarakat agar datang ke posyandu sedangkan 3 orang yang menjawab dari kelompok kader kurang aktif bersikap acuh pada sasaran posyandu yang kurang aktif dengan mengatakan bahwa bila sasaran posyandu masih kurang aktif datang ke posyandu itu pilihan mereka sendiri karena menurut kader dari kelompok kader kurang aktif mereka sudah menjalankan tugasnya dengan baik. Menurut Notoadmodjo (2003) tingkatan sikap dengan orang tersebut mau dan memperhatikan stimulus yang diberikan yang disebut dengan menerima, kemudian dapat menjadikan orang lain dalam mengerjakan dan mendiskusikan suatu masalah yang disebut menghargai.

2. Faktor Pemungkin

a. Sarana dan prasarana kesehatan

Informasi yang didapat dari key informan menyatakan bahwa sarana dan prasarana yang ada sekarang cukup memadai untuk pelaksanaan posyandu seperti dacin, timbangan, meja, kursi, alat tulis dan alat masak untuk makanan tambahan. Hal yang sama juga diungkapkan oleh peserta FGD yaitu 4 orang dari kelompok kader aktif dan 3 orang dari kelompok kader kurang aktif bahwa alat-alat yang ada bisa digunakan untuk pelaksanaan poyandu. Sementara bagaimana pelaksanaan posyandu bila sarana dan prasarana tidak memadai key informan menyatakan mengupayakan fasilitas desa yang bisa dipakai seperti meja, kursi dan mengajukan permohonan permintaan alat ke puskesmas. Sementara 4 orang dari kelompok kader aktif dan 3 orang dari kelompok kader kurang aktif peserta FGD menyatakan bila sarana dan prasarana tidak memadai akan menghambat pelaksanaan posyandu dan untuk mengatasinya dapat dengan mengajukan ke pihak puskesmas atau pihak kepala desa. Hal ini seperti dikatakan olehy (Brace:1990, fromberg:1988, Gombone:1991 ) dalam Azwar (1996) mengatakan bila tenaga sarana dan prasarana (kualitas dan kuantiyas) tidak sesuai dengan standar yang telah ditetapkan ( Standart of personnel and facilities ) maka akan sulitlah diharapkan baiknya mutu pelayanan yang dihasilkan.

\section{Faktor Penguat}

a. Tokoh Masyarakat

Informasi yang didapat dari key informan mengatakan bahwa tokoh masyarakat didesa tersebut adalah Kepala 
Desa dan peranan sangat mendukung pada pelaksanaan posyandu misalnya dengan menyediakan tempat untuk posyandu sesekali hadir saat posyandu, dan membantu mengumpulkan warga. Informasi yang sama didapat dari peserta FGD yaitu 4 orang dari kelompok kader aktif dan 4 orang dari kelompok kader kurang aktif bahwa Kepala Desa sangat mendukung dengan kegiatan posyandu misalnya dengan memberikan informasi tentang manfaat posyandu di masjid dan dengan sesekali datang saat pelaksanaan posyandu.

Hasil penelitian ini sejalan dengan hasil penelitian Sudjatmoko (1997) di Puskesmas Bangil Kabupaten Pasuruan Jawa Timur yang menyatakan bahwa peranan tokoh masyarakat dalam kegiatan posyandu dapat meningkatkan pelayanan enam kali lebih tinggi daripada yang tidak terlibat. Disini dapat dilihat bahwa orang menjadi panutan dapat memotivasi orang lain dalam melakukan kegiatan di posyandu.

Rahayu, Santoso Budi dalam penelitiannya di posyandu wilayah kerja puskesmas Kedung Solo (2005) menunjukkan ada hubungan antara motivasi kader dengan dukungan dan pembinaan. Dukungan dan pembinaan yang diberikan akan dapat memobilisasi orang yang berada di sekitarnya dan membantu keterlibatan mereka. Dari mobilisasi mereka akan timbul kesadaran diri masyarakat untuk ikut terlibat didalam kegiatan dan melalui tokoh tersebut mudah disampaikan dan diterima oleh masyarakat.

\section{KESIMPULAN}

Berdasarkan hasil penelitian dan pembahasan diatas, dapat penulis simpulkan sebagai berikut : Dari hasil FGD dan WM didapat bahwa pengetahuan dari peserta terhadap tugas dan peran kader sudah cukup baik, dari semua pertanyaan yang diberikan baik itu kelompok kader aktif maupun kelompok kader kurang aktif mereka dapat menyebutkan hal-hal yang berkaitan dengan tugas dan peran para kader di posyandu. Walaupun mereka hanya menjelaskan secara garis besar dan belum dapat menjelaskan secara menyeluruh. Dari hasil FGD dan WM di dapat bahwa sikap peserta terhadap keaktifan kader posyandu dalam pelaksanaan kegiatan posyandu sudah cukup baik. Walaupun masih ada juga terdapat peserta FGD yaitu dari kelompok kader kurang aktif yang bersifat acuh dengan sasaran posyandu yang kurang aktif. Sarana dan prasarana kesehatan di Posyandu menurut peserta WM dan dua kelompok FGD sebagian besar sudah cukup memadai walaupun masih ada beberapa sarana yang masih perlu dilengkapi untuk lebih mendukung pelaksanaan Posyandu. Dari hasil FGD dan WM didapatkan informasi Peranan tokoh masyarakat terhadap keaktifan kader posyandu dalam pelaksanaan kegiatan posyandu sudah cukup baik, kades yang dijadikan panutan oleh masyarakat memberikan dukungan yang positif seperti dengan hadir pada saat posyandu dan sering memberikan informasi kepada masyarakat tentang manfaat posyandu. Belum adanya pelatihan dan penghargaan yang diberikan kepada kader baik itu dari petugas kesehatan maupun dari masyarakat itu sendiri. Disamping itu kader baik dari kelompok kader aktif maupun kelompok kader kurang aktif mengharapkan adanya peningkatan jumlah uang transport yang dirasakan jumlahnya masih sangat kurang.

\section{DAFTAR PUSTAKA}

Azwar, Azrul.1996 Pengantar Adminitrasi Kesehatan, edisi ketiga, Bina Rupa Aksara, Jakarta.

Depkes RI.2000.Buku kader ( Usaha Perbaikan Gizi Keluarga ). Depkes, Jakarta.

.2014.Sistem Kesehatan Nasional. Depkes, Jakarta.

.2014.Kebijakan Nasional Promosi Kesehatan. Depkes, Jakarta. 
Dinkes.2015.Profil Kesehatan Provinsi

Sumatera Selatan. Dinkes, Palembang

.2016.Profil Kesehatan Provinsi

Sumatera Selatan. Dinkes, Palembang

.2006.Profil Kesehatan Kabupaten

Lahat . Dinkes Kab Lahat

Effendy, N.1998.Perawatan Kesehatan

Masyarakat. EGC, Jakarta

Kresno, S, et all.2000.Aplikasi Metode Kualitatif dalam Penelitian Kesehatan. FKM UI, Jakarta

Moleorg, Lezy J.2016.Metodelogi penelitian kualitatif, edisi kedua, penerbit PT. Remaja Rosdakarya, Bandung.

Notoatmodjo, S, 2016. Pengantar Ilmu Perilaku Kesehatan. FKM UI, Jakarta

Rahayu, S, 2017

Beberapa Factor yang Berhubungan Dengan Partisipasi Kader Posyandu di Wilayah Puskesmas Kedung Solo Kab Sidoarjo Jatim. ( online ), ( http : // adln.lib.unair.ac.id / diakses 10 Agustus 2021

Sudjatmoko, A.2017.Kader Posyandu Membantu Menciptakan Manusia Sehat di Puskesmas. Medika No: 8 Tahun XXIII

Sugiono.2015.Memahami Penelitian Kualitatif. CV Alfabeta, Bandung. 
